\title{
The missile age and post-Stalinist Soviet foreign policy: a review
}

\author{
Arnold L. Horelick and Myron Rush, Strategic Power and Soviet \\ Foreign Policy \\ Chicago, Ill.: University of Chicago Press, 1966. Pp. 225 . $\$ 5.95$.
}

\section{WILLIAM ZIMMERMAN}

Department of Political Science, University of Michigan

A useful intellectual exercise, it has been appropriately suggested, involves specifying those changes in technology whose occurrence one regrets in retrospect; or, to put the matter more colloquially, identifying the inventions one would wish to "uninvent." Not too many years ago, the case might have been plausibly advanced that the members of the Soviet ruling group had little, if any, reason to regret the series of technological innovations culminating in the development of long-range, multimegaton weapons systems. And, in fact, in the years immediately following the initiation of the missile age, the members of the Soviet ruling group treated its advent as an historically "progressive" development. (There were hints, however, that not every member of the Soviet ruling group attached equal political significance to the advent of the missile era.) Such an appraisal was not surprising inasmuch as intercontinental ballistic missiles were first tested by the Soviet Union -an accomplishment which lent greater plausibility to the assertion that socialism was the wave of the future and which cast doubt on the technological superiority of the West. More importantly, the new weapons permitted the Soviet Union, for the first time really, to achieve world power status, and deprived the United States of its position of strategic invulnerability.

Khrushchev attached particularly great significance to this latter development. In fact, it served as the main buttress for the argument developed by Soviet ideologues in 1960-61 that-in the absence of the world wars which prompted the first and second stages of capitalism's general crisis and resulted in, respectively, the Bolshevik seizure of power in Russia and the formation of the Soviet camp-there had begun in the mid1950s a new, third stage in the general crisis of capitalism, which was to be accompanied by appropriate gains for the forces of socialism.

It is doubtful whether in the mid-1960s the present dominant figures in the Kremlin or their immediate predecessor still consider the postwar transformations in weapons technology a boon to Soviet interests. One rather suspects they would prefer to see these weapons uninvented. It is not so much that "the atomic bomb does not observe the class principle" (as the Soviet leadership has emphasized to the Chinese), 
but rather that the existence of atomic weapons and long-range delivery systems has restricted the operation of the "world historical process" and placed severe constraints on those who would contribute to the acceleration of that process. Militarily, the Soviet leaders now find themselves in a position of distinct strategic inferiority; Soviet political gains in the 1960s have been modest; and the promise of revolutionary advance, which in 1960-61 seemed imminent, remains unfulfilled.

In Strategic Power and Soviet Foreign Policy, Arnold L. Horelick and Myron Rush have provided an account of the manner in which Soviet decision-makers in the postStalin period have responded to and attempted to exploit to political advantage the changes in modern weapons technology and in the global distribution of strategic power. Horelick and Rush devote considerable attention to the gradual escalation by Khrushchev of claims concerning Soviet missile capabilities during the period 195760. They detect a pattern of systematic "deception" of the West, motivated in their view by Khrushchev's desire to secure political gains in Europe, especially in connection with Berlin: "In retrospect it seems clear that the Soviet leaders decided to create a fictitious ICBM force as a means of extracting political concessions from a far more powerful opponent" (p. 109). Moreover, Horelick and Rush contend, the exaggerated ICBM claims were intended to permit Moscow to have it both ways: not only did Khrushchev attempt to acquire political advantage commensurate with the ostensibly changed distribution of strategic forces, but at the same time the fictitious ICBM force provided a façade behind which the Soviet Union could proceed confidently in the orderly procurement of second-generation intercontinental missiles.

Several developments in 1960-61-the intensifying polemic with China, the U-2 incident, and the conclusion by Washington in 1961 that the alleged missile gap was a myth-are pointed to by Horelick and Rush as inducing the Soviet regime to back away from its more implausible assertions concerning the global distribution of strategic forces. More importantly, with the missilegap notion exposed for the myth it was, the authors contend, the Soviet government eased its pressure on Berlin and turned instead to the creation of a strategic environment in which Soviet strategic threats might be more effective as an instrument for inducing desired political change. This, Horelick and Rush argue, Khrushchev attempted to accomplish by installing the IRBMs in Cuba while engaging in still another form of deception-“a denial that the USSR was in the act of acquiring a new strategic capability" (p. 140).

Once that deception was detected by the United States, skillful American orchestration of the US's overall strategic superiority and local military superiority (when combined with Soviet unwillingness to risk central war) resulted in a Soviet withdrawal. Moreover, the Cuban missile crisis prompted a major reappraisal by Khrushchev of the role of strategic threats as an instrumentality in Soviet foreign policy. In the last two years of the Khrushchev era, the priority accorded strategic threats was downgraded. Khrushchev seemed increasingly willing to settle for strategic inferiority; and, Horelick and Rush stress, under conditions of strategic inferiority, Khrushchev opted for a policy of détente with the United States and turned increasingly to economic and military aid, rather than strategic threats, to enhance the Soviet Union's international position. 
Although considerable space is given over to speculation about the strategic options the post-Khrushchevian ruling group may adopt, post-Khrushchevian foreign policy is accorded (for readily understandable reasons) only scant attention. Horelick and Rush do suggest that, while in the initial months after the coup "Soviet strategic forces retained roughly the same relatively limited role ... that of neutralizing the strategic forces of the United States" (pp. 215-16), the bombing of North Vietnam in February 1965 (a) challenged the "very heart of the USSR's claim to leadership in the Communist world" (p. 174), (b) demonstrated that "the threshold for Soviet involvement in hostilities against the United States was . . . even higher than had been implied by Soviet declaratory policy" (p. 216), and (c) may have increased "Soviet incentives to match or surpass the United States in strategic power" (p. 174).

Thus, according to Horelick and Rush, it remains to be seen whether the postKhrushchevian leadership will accept continued strategic inferiority or instead set for itself the task of securing strategic parity with the United States. In any event, Horelick and Rush are persuaded that continued American strategic superiority facilitates international political stability and contributes to the deterrence not only of war but also of "the dangerous employment of Soviet strategic power for political ends" (p. 218).

One major objection to the Horelick and Rush analysis concerns the importance which they attach to strategic superiority as an element shaping the extent to which, and the manner in which, modern weapons technology has altered the behavior of the Soviet Union. The reader of Strategic Power and Soviet Foreign Policy is apt to lose sight of the fact that, in the Soviet appraisal, the crucial breakthrough consisted in the acquisition by the Soviet Union of the most modest "soft" second-strike capability against the United States. As Horelick and Rush quite properly emphasize, Soviet weapons procurement policy in the late $1950 \mathrm{~s}$ strongly suggests that, at that time, Khrushchev at least was not overly concerned about American preemption in the absence of provocation. Nevertheless, with a modest capacity to strike the United States, the Soviet Union was-to borrow a phrase from Arnold Wolfers-no longer at the mercy of our good intentions. In the Soviet perspective, moreover, the passing of American strategic invulnerability fundamentally altered the structure of the international order; the rules of the international game were no longer defined by "imperialism" alone.

The reader may also remain unpersuaded by the effort of Horelick and Rush to depict so much of Soviet behavior as being in response to a particular distribution of strategic forces (i.e. American strategic superiority); he may continue to wonder whether Soviet behavior would have differed greatly had mere mutual deterrence prevailed. (Judging by Soviet declaratory statements, it would seem that Soviet commentators were more concerned with the fact that the United States had "atomic teeth" than with the particular distribution of atomic teeth in the world.) The irreverent reader may even find ironic the significance which Horelick and Rush ascribe to superior strategic power in animating Soviet foreign policy when, according to their account, Khrushchev did everything to secure the benefits of an ostensible change in the global distribution of power except actually attempt to achieve strategic superiority.

It is possible, furthermore, that the authors, in their preoccupation with strategic 
power, have underestimated the effect of changing strategic doctrines and overall force structures on the character of the Soviet (and American) response to the missile age in the years 1957-62. One reason Khrushchev may have thought he could achieve political gains by speaking loudly while wielding a relatively small stick may have been that in the late 1950s the United States, as a result of the "new, new look" policy, found itself in a strategic bind with few options other than "humiliation or holocaust" because of its excessive reliance on strategic power. Maxwell Taylor's doctrine of flexible response (when adopted in 1961) deserves a major part of the credit for undermining Soviet efforts to combine minimal deterrence with rollback. Ironically, part of the Soviet Union's dilemma during the Cuban missile crisis may have been that it found itself in an analogous strategic bind (to the extent that it had implemented the "new look" policy advocated by Khrushchev in January 1960).

The authors' attention to changes in the distribution of strategic forces may have obscured another important point: namely, that (especially under conditions of mutual deterrence) much of the game of politics is given over to attempts to persuade the adversary that something is a cherished value. The relative intensity of values and the perception thereof by the relevant actors may have as great an impact on the outcome of a political controversy as changes in the distribution of strategic forces or changes in the perception of the distribution of strategic power.

A further objection to the Horelick and Rush analysis relates to their somewhat overdrawn account of Soviet "deception." Horelick and Rush do not provide the reader with sufficient guidelines for determining whom, at which juncture, Khru- shchev was deceiving: American and West European audiences, non-Soviet Communists, key Soviet subelites, members of the Soviet ruling group. Was he, perhaps, deluding himself? There is little reason to quarrel with the argument that Khrushchev's statements in 1957 (made only to Western newspapermen and public figures) and the TASS statement in September 1962 (that the USSR was sending arms to Cuba "solely for defensive purposes") were targeted to Western audiences. On the other hand, it is somewhat misleading to present an interpretation of the evolution of Soviet declaratory postures in the late 1950s, concerning the advent of the missile age, which does not give considerable attention to a self-engendered optimism among the Soviet ruling group. Such an interpretation ignores the doctrinal significance attached to Soviet missile achievements (aside from exaggerated claims about specific strategic capabilities) by the Soviet leadership and its spokesmen. Similarly, in instances like Khrushchev's January 1960 speech to the Supreme Soviet, it behooves Horelick and Rush to explain and justify the decision to stress the foreign manipulative aspects of such a statement rather than treat it as being directed primarily to Soviet domestic audiences.

A reason for the absence of such an explanation, one fears, is that it did not occur to them as necessary because, by and large, they write as though "some modification of the totalitarian character of the Soviet regime" (p. 182) is a development-were it to happen-for the future. One would have thought that most analysts of the Soviet scene would, by 1966, agree with Robert Tucker that, for the time being anyway, the Soviet Union is "post-totalitarian." In any case, Horelick and Rush's general inattention to the Soviet internal 
political process produces a somewhat distorted portrait of Soviet foreign policy. The reader gains from their account an impression of a Soviet leadership conducting a superbly orchestrated foreign policy, skillfully utilizing its declaratory statements to augment other foreign policy modes, and operating without the internal audience constraints imposed on more pluralist polities. Such a perspective on Soviet foreign policy has severe limitations as description, and as prescription it may serve to justify an American military policy which, measured as a response to other conceptions of the probable adversary, might be judged over-vigilant. Examples of major foreign policy controversy abound throughout the Khrushchev era: there was, for instance, persistent and open opposition to Khrushchev's notions about military strategy from conservative elements in the armed forces, and disarray ${ }^{1}$ among the specialists

${ }^{1}$ On one occasion during the Cuban missile crisis, as Horelick and Rush note, it was not possible to coordinate pages 1 and 3 of Izvestiia, even though that paper was then edited by Khrushchev's son-in-law. While the disarray in this instance was probably not a function of internal controversy, it does help to caution us against overemphasizing the skillful coordination of Soviet foreign policy. and within the elite concerning the relevance of the Clausewitz dictum in the atomic age--both matters directly pertinent to a consideration of the uses of strategic power.

Regrettably, Horelick and Rush's inattention to Soviet internal political developments is symptomatic of a more general propensity to assume that the nature of the Soviet polity and Soviet foreign policy goals remained constant for the period analyzed. This leaves the reader wondering to what extent the overall substantive and policyprescriptive conclusions were foreordained. Horelick and Rush's contribution would have been appreciably greater had they explored the effects of the changed international environment on the Soviet internal political process and on the perspectives of those engaged in foreign policy analysis or execution, had they considered what these effects signified for Soviet foreign policy behavior, and then related these to American strategic policy choices. By adopting such a tack, they might have more fully treated the Soviet response to "the novel question of international relations in our time ... the political effect in peacetime of mankind's concern over the consequences of thermonuclear war" (p. vii). 